\title{
EDITORIAL
}

\section{UNA DURA PRUEBA PARA CHILE: EL REPLANTEAMIENTO DEL AÑO 2010}

El 27 de febrero de 2010 sin duda será una fecha imborrable para todos. Ad portas de asumir el nuevo Gobierno, de dar por terminadas las vacaciones de verano, de enfrentar un nuevo año académico y reasumir responsabilidades laborales, nuestro país se vio enfrentado a una dura prueba: el terremoto que significó pérdida de vidas humanas, dolor en muchas personas, grandes destrucciones materiales y, por qué no decirlo, el replanteamiento del año 2010, pues toda agenda, todo proyecto ha debido ser reestudiado y reenfocado después del terremoto.

Esta nueva situación importa, para los chilenos dedicados a los más diversos ámbitos del quehacer público o privado, hacerse cargo de la necesidad de reconstrucción del país, no solo en lo que a infraestructura respecta, sino, y sobre todo, en cuanto a las confianzas y a las certezas que se requieren desde el ámbito contractual-inmobiliario, hasta los derechos y deberes de carácter laboral. Así, el sismo no puede ser la excusa del gratuito incumplimiento, de la falta de empeño o de las paralizaciones injustificadas, pero tampoco puede ignorarse que su ocurrencia ha significado un testeo del funcionamiento total de nuestras instituciones, con variables resultados y con justificados requerimientos hacia el futuro.

El Derecho chileno sin duda es un aspecto institucional fuertemente presionado por estos sucesos. Se requerirá revisar temas diversos asociados con responsabilidades por daños, normas de seguridad, declaración de estados de excepción constitucional, seguros, solo por mencionar algunos. Asimismo, será necesario dar un renovado impulso a proyectos de ley cuya materialización en normas vigentes urge, y los tribunales de justicia deberán aprontarse al conocimiento de causas con características muy singulares, en las cuales el concepto de caso fortuito o de fuerza mayor adquirirá un renovado interés en ser acotado y definido.

La Revista Chilena de Derecho, fiel a servir a nuestro público lector tanto en la entrega de artículos doctrinarios como de actualización jurídica, ha revisado su plan de edición 2010, con el objeto de ir incluyendo contenidos asociados con estas realidades, ya sea en comentarios de las sentencias que se dicten, como en ensayos sobre proyectos y realidades contingentes, como en monografías de estudio sobre situaciones que importarán controversia y que demandarán una adecuada interpretación para asumirlas en plenitud.

En este número, entre tanto, les dejamos importantes estudios en diversas ramas del Derecho, un recuerdo de lo que fue nuestro Aniversario a fines del año pasado y el aporte del querido maestro y amigo don José Luis Cea Egaña como jurista destacado de este número, comentando la nueva ley orgánica del Tribunal Constitucional, entidad 
que ha ido adquiriendo cada vez más importancia en la definición de los derechos fundamentales, en el control de constitucionalidad de las leyes y en el asentamiento de las bases de un Estado de Derecho que ha demostrado su permanencia más allá de crisis y catástrofes.

A nuestros autores, árbitros y sobre todo lectores, los mejores deseos en estos tiempos difíciles y nuestro firme compromiso en los valores y en la tarea venidera de la Nación.

Ángela Vivanco MartíneZ

Directora 